PART I

Period 



\section{Postcolonial, Postwar, Cold War}

On July 16, 1950, a few weeks after the outbreak of the Korean War, a flight of fifty American B-29 bombers dropped five hundred tons of bombs on Seoul's Yongsan neighborhood. The primary target was the Yongsan train station. Built by the Japanese in 1900, it was a major transit hub connecting Seoul to cities in the south and had facilities for manufacturing and maintaining trains; like the rest of the capital, it was in the hands of the North Korean People's Army. US general Douglas MacArthur ordered the attack in an effort to halt the southward advance of the North Koreans. According to an Air Force communiqué issued after the attack, a "large number of bombs fell diagonally across the entire yard," completely severing the tracks and leaving the "yards in flames." "Fire and explosions heavily damaged repair and assembly shops," and many buildings were partially destroyed (figure 1). The Americans considered the bombing a success. The damage was not restricted to the railroad yards, however. The bombs also "demolished and set fire to many buildings surrounding the area" and, according to a North Korean communiqué, "a large number of homes, schools, hospitals, and social facilities were destroyed." The North Koreans noted that "not a small number of inhabitants were killed or wounded." Recent South Korean estimates place the toll of the Yongsan bombing at over fifteen hundred civilian casualties. ${ }^{1}$

Six yearslater, Han Hyung-mo transformed the shattered Railway Transportation Office into an ad hoc studio and South Korea's first designated film production space. Han's art team repurposed the damaged building, whose walls were still standing, into something culturally productive. They patched together a roof out of planks and tarpaulins, and hung lights from a makeshift ceiling. They used the space to shoot the spectacular dance hall scene in Madame Freedom (1956). Han's 


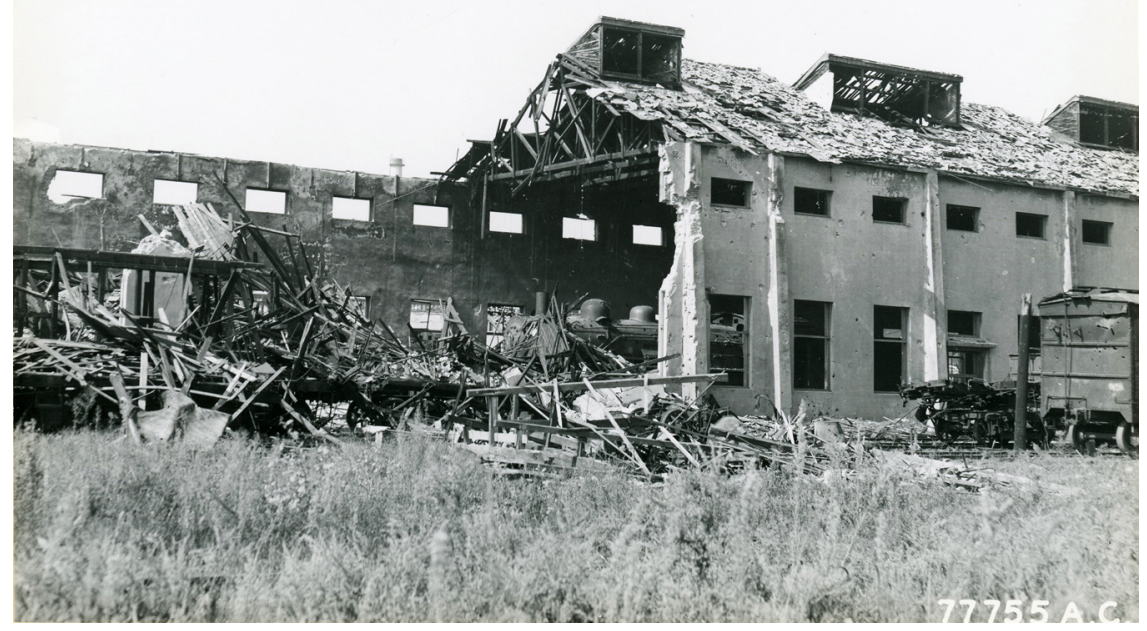

FIGURE 1. Yongsan train station, Seoul, after being hit by American B-29 bombers on July 16, 1950. (Courtesy NARA).

art team built an elaborately arched and tiered stage with soaring columns and a central staircase, flanked by walls decorated with large white circles and basketweave sculptural formations. In this cavernous space, men and women dressed in Korean, Chinese, and Western clothes danced to a Latin jazz band amidst a dozen tables and booths, a palm tree, and a Christmas tree (figure 2). Amidst the postwar rubble, the filmmakers created a place that had no real-world counterpart in South Korea: it was a fantasy of aspiration and desire modeled on images seen in Hollywood movies and American magazines. ${ }^{2}$

The Korean War cleared a space, literally and figuratively, for the production of a distinctive postwar film culture. It shattered what remained of the colonial era's film production system and created an opening for the influx of foreign material and expressive culture that Korean filmmakers appropriated for their own ends. Within a landscape that the war had transformed culturally as well as physically, filmmakers began to produce culturally hybrid—and uniquely Korean - works of film art. Like the studio space constructed out of a Japanese train station shattered by American bombs, these films are redolent of the historical continuities and ruptures across the colonial divide that mark the postwar period.

To read Han's films through the lens of period style requires a thorough understanding of the period in which they were conceived. This chapter charts the historical development of Cold War cosmopolitanism within postwar South Korean political life, focusing on its emergence as a body of material practices and 


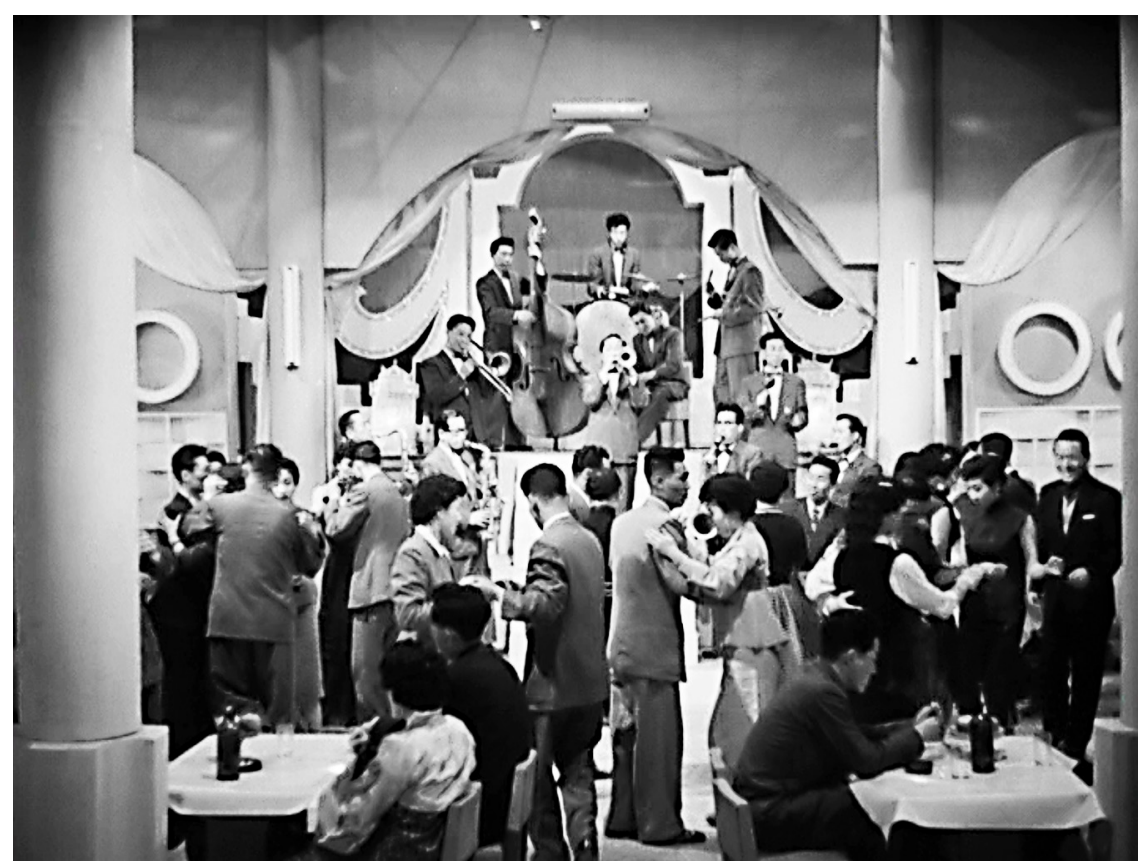

FIGURE 2. The dance hall set in Madame Freedom, which was built in a studio constructed amidst the ruins of the Yongsan train station in 1956. (Courtesy KOFA).

institutional ties aimed at integrating the newly independent nation into the Free World alliance. It introduces the 1950 os as a distinct phase in South Korea's modernization. In the wake of liberation and the Korean War, South Koreans confronted the dual tasks of nation building and bloc building. ${ }^{3}$ They needed to define a new postcolonial national identity, reconstruct a war-ravaged country, and establish ties with other Free World nations. Modernity in the 1950 s was, in part, a consequence of the presence within South Korean's borders of other countries (primarily Japan and the United States) and of the creation of diverse networks that bound South Korea to peoples in Free Asia and the democratic West.

\section{LAYERED MODERNITY: POSTCOLONIAL, POSTWAR, COLD WAR}

The 1950 s was a period of flux and openness that differed in important ways from the colonial modernity that preceded it (1910-45) and the developmental modernity that followed (1961-88). Modernity in the 1950s had a distinctly cosmopolitan dimension. While Korea had relationships with China and Japan stretching back centuries and had encountered the West through the filter of imperial Japan, it now 
found itself engaging in new ways with a broader range of countries. Modernity in the 1950s was shaped first and foremost by the unprecedented, large-scale presence of the United States inside the borders of the country. ${ }^{4}$ Yet Korea's engagement with the world was more complex than simply "Americanization." Korea in the 1950 s was a simultaneously postcolonial, postwar, and Cold War society. Together, these designations point to the layering of multiple foreign presences, and modernities, within Korea's national boundaries. ${ }^{5}$

The Republic of Korea came into being during the first wave of decolonization that swept across Asia in the wake of World War II. Korea had been a Japanese colony from 1910 until 1945, when it was liberated by US and Soviet forces as part of Japan's surrender. The Americans divided the Korean peninsula at the 38th parallel into two zones of Allied occupation, and from 1945 to 1948 the South was governed by the United States Army Military Government in Korea (USAMGIK) and the North, from 1946, by the Soviet-backed Provisional People's Committee for North Korea. In 1948 this temporary division hardened and two separate states were formed, although neither recognized the legitimacy of the other. Kim Il-sung, who had been an anticolonial guerilla fighter in Manchuria, led the Democratic People's Republic of Korea in the North with the backing of Communist China and the Soviet Union. Syngman Rhee, a leader of the Korean government-inexile who had lived in the United States for decades, was elected president of the Republic of Korea (ROK) in the South, which was supported by the United States and the newly formed United Nations. Rhee led South Korea until he was ousted by the student-led April Revolution of 1960 .

Rhee governed South Korea during a period of burgeoning nationalism. During the colonial era Koreans had been economically, socially, and culturally integrated into the Japanese empire, albeit as second-class subjects. Tokyo's cultural assimilation policies, increasingly stringent during the late 1930s and 1940s, mandated the use of Japanese language in schools, restricted the use of the Korean language in public, and recast Korean traditional culture as a mere precursor to that of the more glorious Japanese. ${ }^{6}$ After liberation, South Koreans took up the task of postcolonial nation building with enthusiasm, relishing those expressions of Koreanness that had been quashed under colonial rule. Syngman Rhee espoused a potent form of nationalism rooted in anticolonialism and anticommunism, which he developed into something akin to a civil religion. He gave voice to the great bitterness that many Koreans felt towards Japan, and warned that Japan would soon seek to reassert dominion over its neighbors. Rhee urged Koreans to hold on to their memories of colonial "atrocities" even as they eradicated "Japanese things and ways" (wae-saek), such as food and clothing, from their lives, and he refused to establish diplomatic relations with Japan. ${ }^{7}$ Rhee likewise viewed communist North Korea and its protector, China, as existential threats to the nation. The draconian National Security Law of 1948 outlawed all organizations and activities that could be construed as endangering national security and 
criminalized expressions of sympathy towards North Korea, as well as criticism of Rhee's government. Rhee used the law to restrict democratic liberties and imprison tens of thousands of political opponents. ${ }^{8}$ Rhee's nationalism thus severed South Korea from its two closest neighbors, North Korea and Japan, with which it had extensive historical and cultural ties.

Liberation from Japan did not create an absolute historical break, however, and continuities persisted across the 1945 divide. Elements of colonial modernity, most visibly the broad avenues and multistory buildings that comprised Seoul's downtown, continued into the postwar era. Likewise, the web of connections to Japan did not dissolve overnight. For all Rhee's anti-Japanese rhetoric, he staffed his government with people whose expertise and skills had been developed under the Japanese. Colonial police officers, widely despised as collaborators, morphed into a national constabulary; professionals who had risen through the ranks of colonial bureaucracies continued their ascent in the postcolonial era; and businesses that had partnered with the Japanese expanded after the war. Many Koreans continued to regard Japan, whose economy developed rapidly over the course of the 1950s, as a culturally proximate model of modernity that they might emulate. The "ambivalences of postcoloniality," as Steven Chung has described them, meant that a web of shadowy connections and sub-rosa affinities to Japan coexisted alongside the more public denunciations. ${ }^{9}$

If the bonds of colonialism lingered beneath the surface of the postliberation era, evidence of the recently concluded Korean War (1950-53) was everywhere to be seen. To many observers, poverty defined the 1950s. The economy-already weakened by the global depression of the 1930s, the Pacific War, the withdrawal of Japanese capital and skilled labor, and the loss of access to the industrial capacity in North Korea-was further crippled by the war, which raged up and down the peninsula. According to historian Gregg Brazinsky,

Total property damage from the war in the ROK was estimated at more than $\$ 3$ billion. Three years of fighting had annihilated 900 industrial plants, reduced the textile industry by one-third, and wiped out more than half of the country's freight cars, trucks, and locomotives. Its sawmills, papermills, metal plants, and small industries had almost disappeared. The war had destroyed 600,00o homes and rendered thousands of others uninhabitable. In all, five million South Koreans-roughly a quarter of the country's population-had been forced to leave their homes. Finally, the country's weakened industrial base and shattered agricultural economy produced severe shortages of both jobs and food for an expanding population. ${ }^{10}$

With a per capita income of $\$ 60$ in 1953 , South Koreans were desperately poor, their national income smaller than that of San Francisco's population. Koreans suffered from widespread unemployment that sidelined one of every eight workers and from "wild, flamboyant" inflation that eroded the real wages of those who did have jobs to less than half of what they had been in the late colonial era. The 
social landscape was equally transformed. Out of a population of 21 million, the war had left 1.3 million dead and 5 million destitute, 500,000 widows, and 100,000 orphans. Over 1 million families were separated by the 38 th parallel. Seoul, already full of returnees from the far reaches of the Japanese empire and refugees from the communist north, saw its population swell even further as rural migrants flooded in, to nearly 2.5 million by $1960 .{ }^{11}$ Living conditions were often rudimentary, as people took up residence in bombed-out buildings, sprawling slums, and even caves. "Houses made out of cardboard boxes and cans from the US army bases were built overnight," recalled one inhabitant, "and began to climb the mountains higher and higher reaching the sky." ${ }^{12}$ Crime-including petty theft, juvenile delinquency, prostitution, gangsterism, and black marketing-exploded. Suicides became common. As Bruce Cumings has noted, "South Korea in the 1950s was a terribly depressing place, where extreme privation and degradation touched everyone." ${ }^{13}$ An air of desperation and nihilism suffused the country, and public commentators noted with anxiety the rising pursuit of naked self-interest amidst the erosion of collective social values.

As elsewhere in Asia, however, war proved a modernizing force, wiping out old infrastructure and social relations and creating a partially cleared slab on which to build a new society. Reconstruction gradually restored a semblance of urban order, layering new buildings and infrastructure over the colonial remains. Wardamaged buildings were patched up, orphanages and schools built from scratch, and electricity slowly restored. Used streetcars imported from Nashville carried residents through the streets of Seoul, past department stores, now stocked with American rather than Japanese goods, and Western-style houses built for those who could afford them. ${ }^{14}$ Expanding universities created educational opportunities for middle-class youth, and a reviving textile industry created factory jobs for members of the working class.

This reconstruction was financed through an influx of foreign aid, the overwhelming majority of it coming from the United States. After the war, South Korea emerged as America's largest economic mission in the world: between 1953 and 1961 , it received $\$ 2.5$ billion in economic aid and $\$ 1.5$ billion in military aid from the United States. ${ }^{15}$ As Bruce Cumings puts it, there were "inconceivable amounts of American cash that flowed into the country, down from the presidential mansion, through the bureaucracies civil and military, coursing through the PXs and onto the black market, into the pockets of a horde of people who serviced the foreign presence: drivers, guards, runners, valets, maids, houseboys, blackmarket operators, money changers, prostitutes, and beggars." ${ }^{16}$ This sluicing-in of American cash was accompanied by a similar flood of American food, clothing, medicine, and other goods (much of which was only accessible through the black market: see chapter 6). In an effort to partially privatize its foreign aid program, the Eisenhower administration appealed to ordinary Americans to assist needy South Koreans. American school children "adopted" Korean schools and 
sent them pencils, paper, and books. Religious congregations sent shiploads of sweaters, dresses, pants, and coats. The Ford, Rockefeller, Carnegie, and American Korean foundations dispensed millions of dollars in grants to hospitals, welfare agencies, and other civil society organizations. ${ }^{17}$ By 1958, one umbrella group representing sixty-seven private organizations had donated 12,900 tons of food, worth an estimated \$57 million. Diverse American products seeped into everyday Korean life, especially in the cities. Koreans ate bread and noodles made from American wheat, dressed in outfits refashioned from American military uniforms and parachutes, and rode in taxis that had begun their lives as US Army jeeps. ${ }^{18}$ This influx of aid stimulated South Korea's struggling capitalist economy and gave rise to small middle and nouveau riche classes. The people who prospered in the 1950 s were often those who had access to American resources: bureaucrats who distributed import licenses; businessmen who imported and processed aid commodities such as sugar, wheat, and cotton; and small merchants who sold relief goods in shops. ${ }^{19}$ Savvy entrepreneurs, they found ways to make the aid economy work for them.

This torrent of aid formed the foundation of South Korea's economy. Rhee devoted his energies to extracting as much of it as he could from Washington and inflating its buying power by maintaining an overvalued currency, the hwan. For all its abundance, however, it did not jumpstart an industrial economy. Most aid came in the form of commodities, such as fertilizer and fuel, designed to ensure Koreans' survival in the present, and most American officials believed South Korea's economy would remain primarily agricultural for the foreseeable future. Rhee showed limited interest in industrialization and as a result, according to Gregg Brazinsky, "failed miserably at the task of economic development." Instead he used American aid to stay in power and to reward his political allies, many of whom enjoyed an "opulent lifestyle." ${ }^{\circ 0}$ Corruption existed on a "fabulous scale."

The influx of American money and goods into this desperately poor country imbued daily life with a doubleness that echoed the ambivalent postcoloniality of Korea's relationship with Japan. "Perhaps the most descriptive word for the current Korean scene," wrote one American observer in 1955, "is 'tension." 22 The combination of poverty, reconstruction, and foreign goods created the sense of a society in transition, caught between what it had been and what it might become. Alongside the hardships there was often a sense of optimism about the future. Among the younger generation and those whose lives were a bit less straitened, the armistice raised hopes for positive social change. Liberal ideas arrived with the troops from the United States and the fifteen other UN countries that fought the Korean War. Changing social mores opened up possibilities for new ways of being in the world. The 1950 s was thus a time of contradictions for Koreans. This sense of multiple realities coexisting with one another was manifest in the physical form of Seoul itself, which appeared to US cultural attaché Gregory Henderson as "half city, with mounting buildings, streetcars, electricity, [and] taxis, and half macrocephalic 
monster, growing cancerously in hillside shacks and caves, noisome alleys and settlements without water and electricity." ${ }^{23}$

Postcolonial, postwar South Korea in the 1950 s was also a Cold War society. As Secretary of State Dulles bluntly noted in 1956, "American economic aid was not accorded on the basis of friendship but as a contribution to winning the cold war." ${ }^{24}$ The outbreak of the Korean War in June 1950, coming as it did on the heels of Mao's proclamation of the People's Republic of China in October 1949, shifted the center of the Cold War from Europe to Asia and granted South Korea an importance in Washington's eyes that it had not previously enjoyed. Between 1949 and 1951 the National Security Council issued a series of policy papers, collectively known as NSC 48, that reevaluated Washington's foreign policy towards Asia. NSC 48 acknowledged the "intense nationalism" of new nations emerging out from under Japanese and European colonialism, and it established nation building as one of the foundational principles of US foreign policy, declaring that Washington's primary objective in Asia was to "assist in the development of truly independent, friendly, stable and self-sustaining states." ${ }^{25}$ US interests required that the countries of Asia be able to withstand communist attack and subversion, ally themselves securely with the United States, be governed by leaders regarded as legitimate by their people, and have capitalist economies strong enough to support daily life. In this new political landscape, South Korea became a frontline state with an outsize role in the regional balance of power.

South Korea became a crucial site for the military containment of communism. This, in turn, led to a large American presence within the country's borders. After pouring in 1.8 million soldiers during the Korean War, Washington agreed to maintain two US Army divisions and several Air Force units-a fluctuating force of 50,000-80,000-on a network of about seventy military bases that spanned the country from near the demilitarized zone (DMZ) in its northern region to Jeju Island in the southern, with major posts located in Paju, Seoul, Uijeongbu, Dongducheon, Daegu, and Busan (map 1). (Washington also agreed to maintain an ROK army of up to 720,000 troops. ${ }^{26}$ As the Eighth US Army (EUSA) settled in to stay, it moved into buildings that had been constructed by the colonial Japanese military, a symbolism not lost on Koreans. The sprawling Yongsan garrison in Seoul, located adjacent to the bombed-out train station where Han built his studio, became home to EUSA headquarters and was gradually transformed into an outpost of America, complete with suburban-style houses, big-finned cars, and tow-headed children in swimming pools. ${ }^{27}$ Across the country, American GIs dressed in fatigues and driving jeeps became a common sight on the streets surrounding the US military bases. Select Koreans had access to these bases as soldiers, employees, guests, dance partners, and sexual partners.

The Republic of Korea was an independent country, but it was also a client state of the vastly more powerful United States. Rhee was no American puppet. He often pursued interests at cross-purposes with those of Washington, as in his 


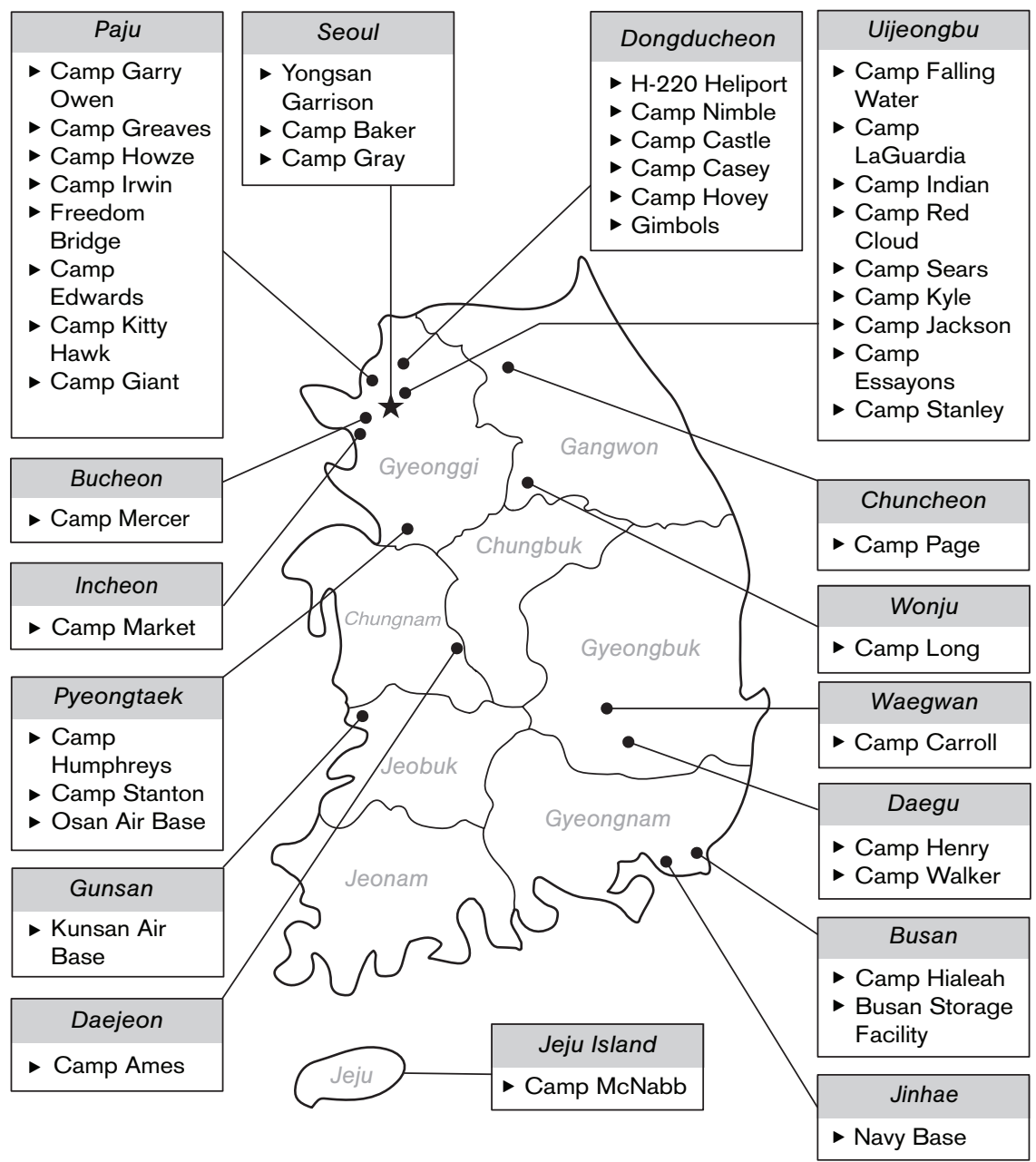

MAP 1. Major US military posts in South Korea, 1950-1960. (Source: Kwang Sub Kwak, "The U.S.-ROK Alliance, 1953-2004," PhD diss., Southern Illinois University Carbondale, 2006).

refusal to restore political and economic relations with Japan and his staunch commitment to an overvalued hwan, and his authoritarian violations of political liberties often frustrated his American patrons. Yet US hegemony over the country was unmistakable. The ROK armed forces, for instance, remained under the UN Command's operational control and thus constrained Rhee's ability to pursue an independent foreign policy, which would likely have included an attack against North Korea. The inequality between the United States and South Korea could be felt across many sectors of society: among the sex workers for whom Americans 
were a source of both income and exploitation, the employees who protested the wages and working conditions on US military bases, and the youthful elite who sought admission into American universities. As Sang-Dawn Lee has noted, the US and ROK established a hierarchical "big brother, little brother" relationship in which the Koreans unambiguously occupied the secondary role. ${ }^{28}$

South Korea became a crucial site for Americans' developing ideas about modernization. Outside the confines of Europe, the Cold War was as much about modernity as political ideology. In the struggle for the allegiance of the newly decolonizing nations, communists and Americans offered competing visions of modernity and how to get there. The American blueprint emphasized capitalism and participation in international markets, the import of consumer goods and advanced technologies, and the growth of democratic institutions. The Soviet blueprint, in contrast, emphasized central planning, heavy industry, collectivized agriculture, and independence from international markets. ${ }^{29}$

Modernization, as understood by Americans, was necessarily a process of social and cultural transformation. As Nils Gilman writes, modernization theory was built around "a particular rendition of the dichotomy of 'the traditional' and 'the modern." Americans believed that "modern society was cosmopolitan, mobile, controlling of the environment, secular, welcoming of change, and characterized by a complex division of labor. Traditional society, by contrast, was inward looking, inert, passive toward nature, superstitious, fearful of change, and economically simple." The task of guiding postcolonial societies towards modernity entailed the cultivation of new values and practices, aimed at nurturing into existence a society that looked more like America, and less like the Soviet Union or China. A central objective was to "make men modern": to transform their consciousness and their understanding of their selves, their relations to others, and their roles in society. To a large extent, this meant adopting the liberal values of universalism, democracy, freedom, equality, and individualism. While modernizers rejected the idea of wholesale Americanization, they did believe that the embrace of these values would erase many of the social limitations that traditional society imposed: according to Gilman, "differences about things like the desirability of social mobility, free speech, or the inclusion of women in the public sphere would necessarily disappear in the course of becoming modern." Cultural differences would still be valued, but as a self-conscious heritage that would be manifest in limited ways, rather than as guidelines for everyday life. ${ }^{30}$

In South Korea, a small army of Americans and their Korean partners sought to implement modernization's blueprint in the fields of government, education, public information, social welfare, the military, and the law. Western standards, adapted to the realities of South Korean conditions, defined the modernity to be achieved. The legacies of Japanese colonialism and the social strictures of Confucianism, in turn, constituted the outmoded ways of life whose constraints would be eased. Both were regarded as antiliberal modes of social organization that fettered the individual, inhibited the development of democratic freedoms, 
and slowed the growth of an egalitarian ethos. "Liberation" from these hierarchical, collectivist systems constituted modernizers' core mission. With some exceptions, Korean political and cultural elites largely embraced this process and regarded Confucianism as one cause of Korea's "backwardness." ${ }_{31}$

South Korean modernity in the 1950 s was thus a complex condition, layered and incomplete and in a state of transition. The development of colonial modernitywhich included factories, communications networks, and a vibrant mass culturehad ground to a halt with liberation. ${ }^{32}$ As a result, the desire to be modern was widespread in the 1950 and modernization was regarded as integral to the project of postcolonial nation building. According to historian Charles Kim, there was a "widely shared assumption that Koreans, for the benefit of self and nation, had to 'modernize' all spheres of life according to Euro-American models." Korean modernizers, like their American counterparts, believed that "the option of returning to an 'old Korea' is long since gone., ${ }_{33}$ Yet the association of modernity with America intersected with Koreans' robust nationalism in complicated ways. How should postcolonial people become modern while simultaneously restoring their sense of Koreanness that the Japanese had tried to crush? While the vast majority of Koreans viewed the United States favorably, these feelings of admiration and gratitude were often shot through with shame, resentment, and anger. ${ }^{34}$ Debates over modernization thus centered not on whether to change, but on how quickly and extensively. At the same time, modernity in the 1950 s possessed something of an unreal quality in that the epiphenomena of modernity abounded in the absence of a solid foundation. ${ }^{35}$ The lack of an industrial economy (which would not develop until the 1960s) meant that Korea did not have the material infrastructure of a genuinely modern society: urbanization was driven by the flood of refugees rather than by any need for factory workers, and the emergent consumer culture was stocked not with Korean-made goods but with items imported, donated, or smuggled in from abroad. Korean modernity in the 1950s was thus largely a social phenomenon rather than a deeply rooted economic one, and a layered experience of both continuities and breaks with the colonial modernity of the prewar era.

\section{INTEGRATION INTO FREE ASIA}

If nation building constituted one guiding principle of Cold War US foreign policy, bloc building constituted the other. For US policy makers, it wasn't enough for South Korea to ally itself with the United States; it needed to ally itself with other nations as well. The Cold War, after all, was a conflict between blocs and systems, not just nations. The National Security Council, for all its understanding of nationalism's powerful appeal, wanted to encourage an outward turn among the newly independent nations of Asia. The drafters of NSC 48 , troubled by the "antipathies" and "lack of affinity among Asian nations," sought to encourage a "consciousness of common interests" and facilitate "regional collaboration" in all 
its varied forms. ${ }^{36}$ The region's security, and ultimately America's, depended on the forging of substantive ties among Asian countries. Washington was keenly aware of the need to nurture Free Asia into existence as something more than an archipelago of noncommunist states. Free Asia would not come into being automatically; it would have to be created. This insistence on bloc building in Asia went hand in hand with modernization theory, which defined modern societies as "cosmopolitan," in contrast to "inward looking" traditional ones. Modernity was constituted, in part, through an openness to new ideas, a willingness to learn from others, and a capacity for exchange. The outward turn that the NSC promoted as a security measure was thus also an essential part of the development process. From this perspective, it wasn't enough that South Koreans welcomed US and UN troops and advisors into their country. To become truly modern, and truly secure, they also had to reach beyond their nation's borders to engage with other noncommunist people. South Korea's integration into the emerging military, political, and economic networks of the Free World produced a more fully cosmopolitan dimension to 1950 s modernity. It also marks the emergence of Cold War cosmopolitanism as a body of material practices and institutional ties.

The phrase free Asia became ubiquitous in postwar American and Asian political discourse, its meaning shifting over the course of the 1940 s and 1950s. While it had anticolonial connotations during World War II, with the outbreak of the Korean War it came into wide usage to characterize the part of the world seen as threatened by communist aggression and subversion. Eisenhower introduced the more evocative "arc of free Asia" in 1955 to identify the recipients of his new foreign aid initiative, which specifically targeted regional integration (map 2). The phrase became American shorthand to indicate Asia's value to the West, from its large population whose political allegiance hung in the balance to the abundance of vital natural resources to which it was home. ${ }^{37}$ Within Asian political discourse, it became a way to affirm affiliation with the West.

Over the course of the 1950s, Washington worked to incorporate South Korea into a series of Free Asia networks. The Mutual Defense Treaty of 1953 incorporated South Korea into Washington's regional military network, a "hub-and-spokes" system that knit the US together with Japan, Taiwan, the Philippines, Pakistan, Thailand, Australia, and New Zealand. ${ }^{38}$ Large as it was, the US military presence in Korea was thus merely one node with a much larger network, ultimately global in scope, that stationed one million troops on over eight hundred military bases around the world. ${ }^{39}$ Korea's political integration was also seen as essential and from 1948 onward, according to State Department historian Donald Macdonald, the "United States constantly encouraged the South Koreans to broaden their international contacts by campaigning for broader recognition, by establishing diplomatic relations, and by joining international organizations." Washington pushed especially hard for a rapprochement with Japan which, as the region's largest and 


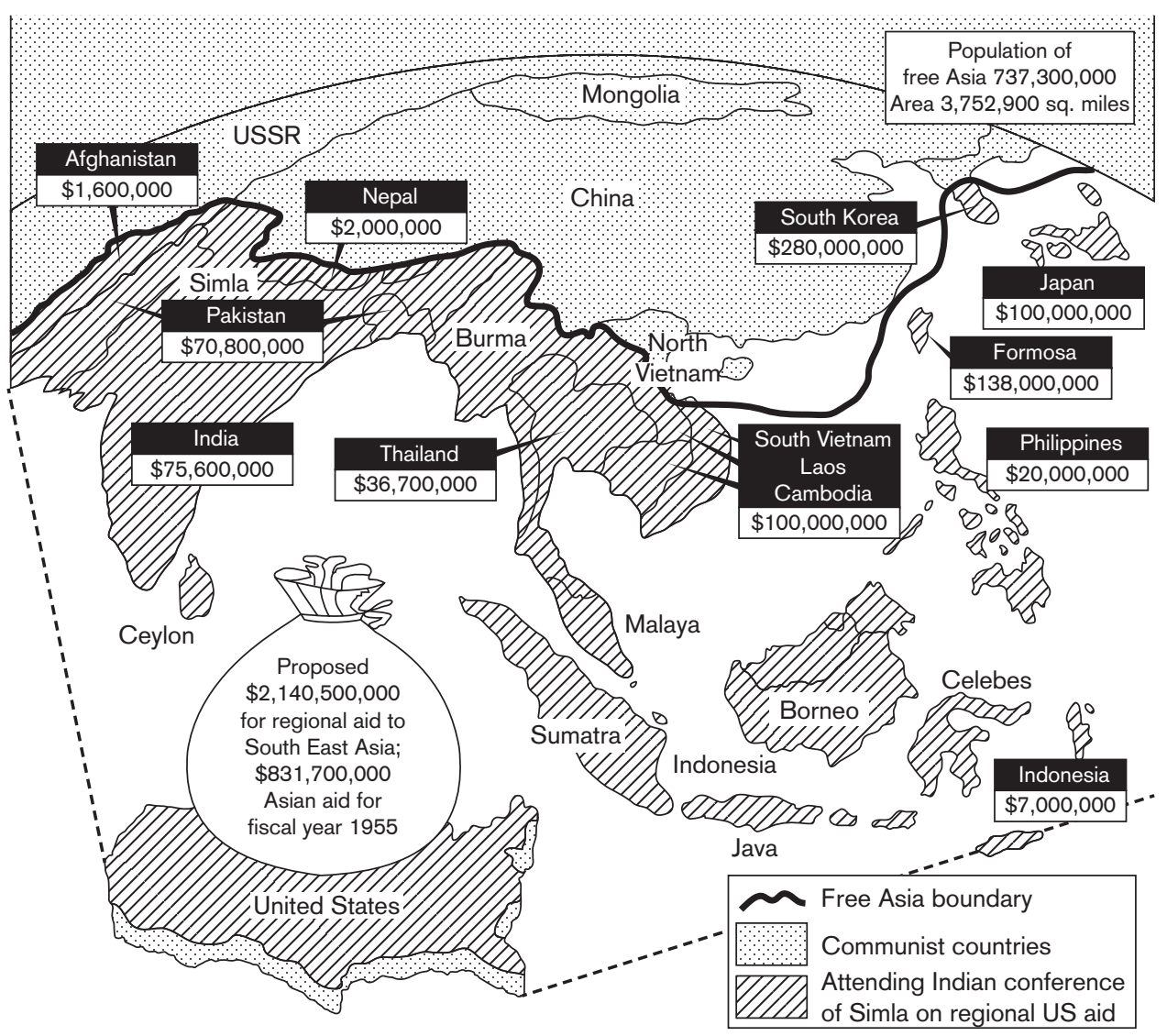

MAP 2. US foreign aid for "the arc of Free Asia" in 1955.

only industrialized economy, was at the center of Washington's conceptualization of Free Asia. The NSC urged the fostering of a "community of interest" between Korea and its neighbors, as well as the creation of concrete opportunities for "joint cooperation" and "multilateral activities." 40 While Rhee did forge close relationships with Taiwan, South Vietnam, and the Philippines, his implacable hostility to Japan precluded any restoration of political ties, and his virulent anticommunism led some other nations to keep their distance. Washington had less success with Korea's economic incorporation. While American officials routinely encouraged Rhee to establish normal commercial relations with other noncommunist countries, particularly Japan, South Korea's exports remained miniscule compared to its imports, and the US remained the country's primary trading partner as well 


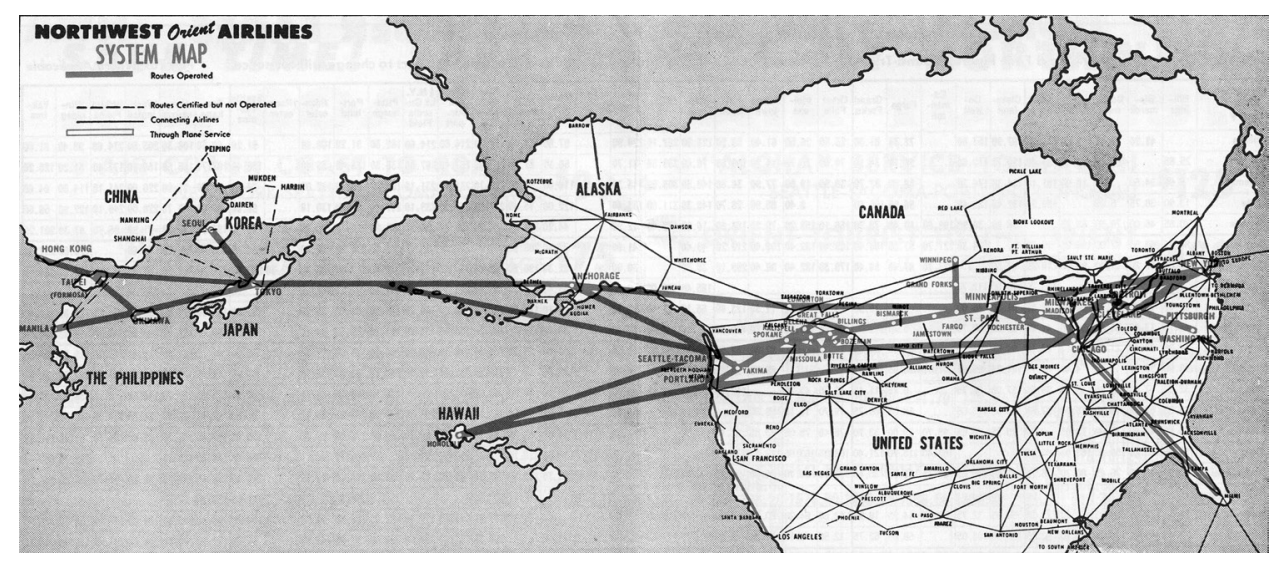

MAP 3. Northwest Orient Airlines System Map, c. 1956. Commercial civilian flights to Seoul began in 1947 .

as aid supplier throughout the 1950 s. $^{41}$ One bright spot was Korea's incorporation into Northwest Airlines' trans-Pacific transportation network, which facilitated the flow of people and information between South Korea, the US, and other nations in the "arc of free Asia" (map 3).42

Syngman Rhee shared Washington's goal of binding Free Asia together via institutional ties, although he had his own ideas about which nations comprised Free Asia and what Korea's role within that community should be. Rhee's ideas overlapped with, but were not identical to, Washington's. Most notably, Rhee sought to exclude Japan and he also regarded with suspicion the merely noncommunist nations of India, Burma, Laos, Cambodia, Indonesia, Sri Lanka, and Pakistan. Rhee's notion of Free Asia privileged avowedly anticommunist nations, and he identified Korea, along with Taiwan and South Vietnam, as its keystones. ${ }^{43}$

Rhee sought to institutionalize his Japan-free vision of Free Asia through formal regional alliances. Beginning in 1949, Rhee worked with Chiang Kai-shek of Taiwan and Elpidio Quirino of the Philippines to form the Pacific Pact security alliance. Despite years of effort, the Pact never got off the ground and it was finally abandoned after Korea signed the Mutual Defense Agreement with the United States in 1953. Rhee had better luck with the Asian People's Anti-Communist League (APACL), which he viewed as the Pact's successor. The League was Rhee's idea and he launched the blazingly ideological and vehemently antineutralist APACL in 1954 at an international conference in Jinhae, South Korea ${ }^{44}$ An international, quasi-governmental organization, it sought to strengthen the political, economic, and cultural ties among the anticommunist nations of Asia. Although the APACL was explicitly aligned with the West, Rhee saw is an opportunity for 
"the free people of Asia" to "do something for themselves." Its growing membership roster reflected its cosmopolitan mission. The initial meeting in 1954 included seven delegates, from South Korea, Taiwan, Hong Kong and Macao, the Philippines, Okinawa, Thailand, and South Vietnam. Three years later its conference was attended by representatives from fifteen localities that spanned Asia, the Middle East, and Europe, as well as emissaries from groups such as the AntiBolshevik Bloc of Nations and the Alliance of Russian Solidarists, who represented the interests of groups in eastern Europe and western and central Asia. Less formally, Rhee in 1954-57 sent General Choi Duk Shin on a series of goodwill missions aimed at forging closer bonds with the nations of Southeast Asia. In scores of meetings and cocktail receptions in the region's capitals, Choi told South Korea's story and listened as local leaders told theirs. ${ }^{45}$

\section{THE CULTURAL COLD WAR IN ASIA}

The work of bringing Free Asia into existence and fostering South Korea's integration into it was taken up the agencies of the cultural Cold War as much as by the departments of State and Defense. By the "cultural Cold War," I mean the efforts by the US and other national governments to achieve political ends through social and cultural means. America's instruments for waging the cultural Cold War had their roots in the propaganda machinery of World War II and began developing from the late 1940s onward as a result of Truman's, and especially Eisenhower's, calls for information and psychological warfare campaigns. ${ }^{46}$ NSC 48 laid the foundation for the cultural Cold War in Asia when it called for an information campaign that would generate "maximum support both at home and abroad" for US objectives in the region. ${ }^{47}$ The cultural Cold War in Asia took off in 1954-56. In the wake of Stalin's death and the Korean War armistice in 1953, Cold War conflicts shifted onto a more ideological plane. At the Geneva conference in 1954 and Bandung in 1955, China launched a "peaceful coexistence" campaign designed to recast its revolutionary image into that of a responsible world power that posed no threat to its neighbors. Turning to strategies of diplomacy and persuasion, it set out to win the allegiance of Asia's neutral populations, assert its leadership of the emerging nonaligned movement, and divide the US from its allies. By 1955, Washington regarded China's cultural initiatives as a serious threat and began to ramp up its own efforts across the region, where Americans often felt themselves to be playing catch-up to communists' more sophisticated techniques. What followed, according to Gregg Brazinsky, was "all-out cultural warfare" in which the United States and China promoted their own "ideologically determined visions of global community with clearly defined adversaries that needed to be excluded." 48 The 1950 s was thus a remarkably dynamic period in which competing, outside interventions in Asia's social and cultural spheres became widespread, often with long-term, transformative effects. 
The cultural Cold War aimed to shape the consciousness of Asian populations, winning the hearts and minds of elites and masses alike. Washington waged it both overtly and covertly. The USIA, created in 1953 (and known as USIS overseas), became America's central instrument of the cultural Cold War, producing information and propaganda materials that were distributed globally and often identified as products of the American government. ${ }^{49}$ The cultural Cold War was also waged in a less forthright manner. Kenneth Osgood has documented Eisenhower's "camouflaged" approach to propaganda, which entailed enlisting the services of a vast array of private individuals and groups to act as surrogates promoting American objectives. This strategy created a "private façade" that masked the involvement of American officials and obscured the propagandistic nature of the work being done. These seemingly private entities generally engaged in long-term information operations that sought to permanently shape the beliefs of artists, intellectuals, and other elites in the developing world. These "slow media" operations, as Osgood calls them, promoted an "ideology of freedom" that sought to inculcate the liberal ideals of democracy, individual rights, and personal responsibility. They also promoted internationalist values, such as universalism and religious faith, that encouraged a sense of engagement with other Free World peoples. These values were disseminated through a broad array of channels, including books, literary and political journals, educational and leadership exchange programs, and diverse people-to-people programs. ${ }^{50}$

The Asia Foundation was Washington's primary "camouflaged" entity waging the cultural Cold War in Asia, and one of the most important instruments working to bring Free Asia into existence. An ostensibly private philanthropic organization, the Asia Foundation (TAF) was a CIA front organization, one of the most expansive created during the early years of the Cold War. The CIA financed covert operations around the world in part by funneling large amounts of money through private foundations, such as Ford, Rockefeller, and Carnegie..$^{11}$ With TAF, it created its own foundation. TAF played a singular role in the cultural Cold War in Asia: alone among US agencies, it had as one of its core objectives the fostering of bonds between Free Asian nations by stimulating exchange and cooperation across national borders. ${ }^{52}$ The Asia Foundation started life at the height of the Korean War in 1951 as the Committee for a Free Asia (CFA), a name that helped solidify the Cold War meanings of that phrase. Created and fully funded by the CIA, its secret mission was to engage in "psychological warfare in the informational field." It was designed to "have the freedom and flexibility to do things the government would like to see done but which it chose not to do or could not do directly." ${ }_{33}$ As with many other front organizations created in the late 1940s and 1950s, the inspiration for the CFA was derived, in part, from the Soviet Union's Popular Front strategy of the 1930s: the CIA admired the Left's ability to mobilize large groups of ordinary people on behalf of an internationalist agenda by tapping into their particular interests. ${ }^{54}$ The CFA soon attracted criticism for its stridently 
anticommunist tone, however, and in 1953-54 the CIA relaunched it as the Asia Foundation under the more sophisticated leadership of Robert Blum, a seasoned intelligence officer with close ties to agency director Allen Dulles.55

The Asia Foundation was headquartered in San Francisco, where a staff led by Blum and James L. Stewart, the director of operations, oversaw a network of branch offices across Free Asia, each of which was headed by an American "representative" and supported by local employees. The representatives, many of whom had missionary backgrounds or prior careers in journalism or with government agencies such as USIS, had a good deal of autonomy in how they allocated funds, although the San Francisco office and CIA headquarters kept close tabs on all activities. By 1956, the Asia Foundation had offices in thirteen localities, stretching along the "arc of free Asia" from Afghanistan in the West to Japan in the East. ${ }^{56}$

TAF focused on nurturing Asian initiatives. Blum and the local representatives provided resources for individuals and organizations that were working towards suitably noncommunist goals. The Foundation made direct grants of money, provided equipment and supplies, encouraged private American organizations to assist their Asian counterparts, and offered advice and moral support. ${ }^{57}$ While TAF provided most of this support openly, it sought to keep its Asian beneficiaries, rather than itself, in the foreground. TAF had a relatively modest budget: $\$ 150,000$ in 1951, \$1.4 million in 1952, \$3.9 million in 1953, \$3.1 million in 1954, \$5.1 million in $1955, \$ 5.6$ million in $1956, \$ 6.5$ in 1957 , and $\$ 6.8$ million in $1958 . .^{58}$ It typically made small grants-anywhere from a few hundred to fifty thousand dollars-directly to Asian organizations, and it generally provided seed money to get a project launched or interim funds to tide over a rough patch, rather than ongoing funding. In keeping with its commitment to capitalist democracy, it aimed to stimulate enterprises that could go on to become self-sustaining. As a result, it gave grants to thousands of recipients across Asia. Unlike USIS, TAF did not produce or dictate content. It sought to stimulate politically sympathetic local practices rather than use local instruments to disseminate American-produced content. Once it decided an organization or individual was worth supporting, it generally maintained a hands-off approach; its ideological work was in the choice of whom to support, not in micromanaging what they did. The foundation typically made grants in response to direct application from Asian individuals and organizations, although it sometimes fostered the creation of a group if it found a compelling program area that did not have adequate institutional support.

The ultimate objective of TAF's philanthropy, according to the CIA, was to "insure political developments in host countries favorable to the United States." To this end, TAF also functioned as an intelligence-gathering operation: through its extensive contacts with Asia's social, cultural, and political leaders, it collected information "not otherwise available to the Agency" and passed it on to the CIA through a steady flow of reports. The CIA relished the "depth of access" the foundation enjoyed and in 1964 gloated that no communist government had among 
its assets "an independently-chartered organization with capital and personnel capable of making such wide and varied impact throughout Asia." The Asia Foundation's "image, flexibility and effectiveness," exulted the agency, "appear to be unique." 59

The Asia Foundation made its first foray into Korea in 1951 when it delivered a thousand tons of newsprint for textbook publishing. It established a Seoul office in 1954, and was soon disbursing about $\$ 200,000$ a year to support a wide range of projects, directing its resources towards intellectuals and the fields of education, culture, and communication. ${ }^{60}$ The office was run by a series of representatives who served relatively short terms: Philip Rowe, who died suddenly in office from polio (1954-55); Mary Walker, who stepped in as acting representative (1955-56); Lawrence G. Thompson (1957-58); and John E. (Jack) James (1958-60). They were assisted by six full-time Korean staff members, including program advisor Cho Tong-jae and program consultant Cho Pung-youn. ${ }^{61}$

TAF's Seoul representatives worked to inculcate a Cold War cosmopolitan worldview among postcolonial Koreans, in part by facilitating their entry into transnational networks. The foundation was deeply concerned that Japanese colonialism had left Korea a provincial and isolated nation, and so it devoted a great deal of energy to fostering ties between Korea and other Free World countries. TAF pledged to support projects that promoted "Korean understanding of the modern world, its goals, and its ideologies," that encouraged "Korean ties with the Free World," and that facilitated the "exchange of Korean and other Free World experience." ${ }^{2}$ The Seoul office targeted many of its grants in order to bring this worldview into existence. While the Korean government closely controlled overseas travel by its citizens in an effort to limit the outflow of hard currency, TAF representatives enthusiastically supported overseas travel within Free Asia and the Free World. TAF regarded such travel as essential for ending Korea's historical isolation, for enabling Koreans to learn about other cultures, and for making Korea known to the larger world. Travel to international conferences received abundant support. In the 1950s TAF sent South Koreans to intellectual and professional gatherings across Asia, Western Europe, and the United States. These conferences helped knit South Korea into the Free World-and bind the Free World togethervia institutional and personal networks, as members of its educated elite joined international civic and professional organizations. A broad spectrum of people were drawn into these networks, including scholars, teachers, writers, scientists, lawyers, Buddhists, Christians, Girl Scouts, musicians, and farmers. In facilitating the travels of South Koreans across the Free World, the Asia Foundation helped fulfill the NSC's recommendation to cultivate political and moral support for Korea among other nations and to develop Korea's own sense of belonging to a "community of interest" among noncommunist peoples. ${ }^{63}$

The political goal of binding South Korea to the Free World intersected with the social goals of modernization, and led Washington to invest heavily in inculcating 
among prominent Koreans a strong sense of connection to America. Washington cultivated emerging leaders by immersing them directly in American life. The State Department Leadership Grants program, the International Cooperation Administration, the Defense Department, and numerous private foundations sent thousands of Koreans to the United States to experience democratic capitalism and American-style modernity firsthand. Rising politicians observed Congress and state legislatures in action, newly minted officers received advanced military training, and over forty-seven hundred Korean students enrolled in American universities. Hundreds of professionals from the worlds of media, education, engineering, agriculture, and medicine traveled to the US for instruction and observation, staying anywhere from a few weeks to several months. ${ }^{64}$ These programs cultivated an educated elite that identified with the United States and embraced many of its liberal values, on the premise that these leaders would influence the views of the majority population.

The waging of the cultural Cold War in Korea, like its political and military counterparts, had as one of its core objectives the enmeshment of South Korea into an array of Free Asian and Free World networks. While the vast majority of Koreans were rural peasants with little substantive contact with the world beyond their country's borders, thousands of educated Koreans participated in transnational activities that spanned oceans and continents. Through the efforts of Koreans and Americans alike, Cold War cosmopolitanism emerged as a vitally important dimension of elite postwar society. 